\title{
IQTISHODUNA
}

IQTISHODUNA: Jurnal Ekonomi Islam

E-ISSN: 2443-0056, P-ISSN: 2252-5661

Accredited Sinta 2 Number 148/M/KPT/2020

Volume 9 Issue 2, October 2020 | Page: 137-150

DOI: $\underline{\text { doi.org/10.36835/iqtishoduna.v9i2.489 }}$

\section{Stock Selectivity Skill, Market Timing Ability, Risk, Size, and Comparison of Performance Sharia Mutual Funds}

\author{
Elliv Hidayatul Lailiyah", Rahmat Setiawan²
}

\author{
${ }^{1}$ Departement of Sains Manajemen, Faculty of Economics and Business, Universitas Airlangga \\ Jl.Airlangga No.4, Surabaya 60286, Indonesia \\ ${ }^{2}$ Departement of Sains Manajemen, Faculty of Economics and Business, Universitas Airlangga, \\ Jl.Airlangga No.4, Surabaya 60286, Indonesia \\ e-mail: $\underline{1 \text { ellivhidayatullailiyah@gmail.com }}{ }^{2}$ rahmatsetiawan@feb.unair.ac.id
}

\begin{abstract}
The Muslim population in Indonesia is one of the highest at around $87 \%$. The high population of the Muslim in Indonesia should be able to provide great potential in terms of Islamic finance as an investment activity, which will certainly contribute positively to the Indonesian economy. Investors will always be interested in investment with high returns and low risk. One of the alternatives is mutual funds, especially sharia equity mutual funds. The choice of the right mutual fund should pay attention to how the performance of the mutual fund. This study examines how the performance of sharia equity mutual funds using the Sharpe, Treynor, and Jensen methods are affected by stock selectivity skills, market timing ability, risk, and size during 2012-2017. The finding of this research is stock selectivity skills, market timing ability, risk, and size are a significantly positive influence on the performance of sharia equity mutual fund. The influence of stock selectivity skill, market timing ability, risk, and size are very strong if measured by the treynor method.
\end{abstract}

Keywords: sharia equity mutual fund, performance

\begin{abstract}
Abstrak: Populasi penduduk Muslim di Indonesia merupakan salah satu yang tertinggi yaitu sekitar 87\%. Tingginya populasi Muslim di Indonesia dapat memberikan potensi yang besar dalam keuangan syariah seperti dalam aktivitas investasi, yang tentunya akan berkontribusi positif dalam perekonomian Indonesia. Investor akan selau tertarik dengan investasi yang memiliki return tinggi dan risiko yang rendah. Salah satu alternatifnya adalah reksadana khususnya reksadana saham syariah. Pemilihan reksadana yang tepat harus memperhatikan bagaimana kinerja dari reksadana tersebut. Penelitian ini menguji bagaimana kinerja reksadana saham syariah dipengaruhi oleh stock selectivity skill, market timing ability, risiko dan ukuran reksadana (size) selama periode 2012 hingga 2017. Temuan penelitian menunjukkan bahwa stock selectivity skill, market timing ability, risiko dan ukuran reksadana signifikanberpengaruh positif terhadap kinerja reksadana saham syariah. Pengaruh stock selectivity skill, market timing ability, risiko dan ukuran reksadana sangat kuat apabila diukur menggunakan metode pengukuran kinerja treynor.
\end{abstract}

Kata kunci : reksadana saham syariah, kinerja

\section{Introduction}

Investment activities related

to the capital market. The capital market has a role in the country's economy. This is because the function of the capital market is to obtain funds from investors, as a means of funding used for business 
development. In addition, it is also a means to invest in financial instruments, so that investors can place their funds in accordance with the risks and benefits of each instrument ${ }^{1}$

Investment activities can be said as activities that do not use funds for consumption at this time but are used for businesses in the hope of getting greater profits from the business in the future. The purpose of investing is to maximize return or profit by considering the risk. Risk and return are both very related things. Every investment expectation in the future there will certainly be potential risks that occur in these investments. The future always has uncertainty, where the uncertainty is a risk ${ }^{2}$.

At present, Islamic finance has grown rapidly in the world. The Islamic financial system has also been developed by many countries with a majority of non-Muslims, not only the majority of Muslims. The Muslim population in Indonesia is one of the highest. The 2010 population census data states that the population of Muslims in Indonesia is $87 \%, \quad 207,176,162$ Muslim residents out of $237,641,326$

\footnotetext{
${ }^{1}$ Bursa Efek Indonesia. Pengantar

Pasar Modal,

https://www.idx.co.id/investor/pengantar -pasar-modal/
}

${ }^{2}$ Hadi, N. Pasar Modal Acuan Teoretis dan Praktis Investasi di Instrumen Keuangan Pasar Modal. Yogyakarta: Graha Ilmu. 2013 :193.
Indonesian population ${ }^{3}$. The high Muslim population in Indonesia should be able to provide great potential to be developed, especially in terms of Islamic finance, which will certainly make a positive contribution to the Indonesian economy.

Increasingly crowded investment activities are driving factors for the emergence of various alternative investment products. Investors prefer investments that have high return and low risk. The problem is investors have different funding capabilities, meaning some investors only have funds that are not large enough. One solution or alternative is through mutual funds. Related to Islamic institutions, one of the fastest growing Islamic financial institutions in Indonesia are sharia mutual funds. Sharia mutual funds are mutual funds based on Islamic principles in carrying out their investment activities.

Empirical data in figure 1 ${ }^{4}$ shows an increase in the number and Net Asset Value (NAV) of Islamic mutual funds in Indonesia. The increase in the number of mutual funds from 2010 to 2017 was very significant at $279 \%$. While for mutual funds NAVs also

\footnotetext{
${ }^{3}$ Badan Pusat Statistik. Penduduk Menurut Wilayah dan Agama yang Dianut.http://sp2010.bps.go.id/index.php/ site $/$ tabel?tid $=321$

${ }^{4}$ Otoritas Jasa Keuangan. Statistik Reksadana Syariah. https://www.ojk.go.id/id/kanal/syariah/ data-dan-statistik/reksa-danasyariah/default.aspx
}

138| Copyright (C) 2020, IQTISHODUNA: Jurnal Ekonomi Islam

http:/ / ejournal.iaisyarifuddin.ac.id/index.php/iqtishoduna 

Ability, Risk, Size, and Comparison of Performance Sharia Mutual Funds

experienced the same thing, there was an increase of $441 \%$ from 2010 to 2017.

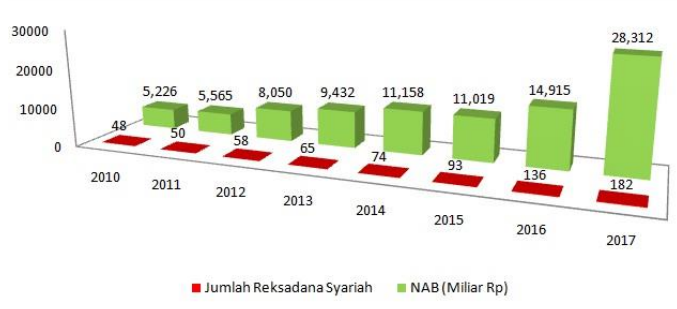

Figure 1. Development of Sharia Mutual Funds and Net Asset Value

Source: Financial Services Authority, 2018

Mutual fund performance is something that needs attention, because performance will determine the results and profits to be obtained by investors. There are several things such as stock selectivity skills or the skill of investment managers to make share choices, market timing abilities or the ability of investment managers in market timing, risk and the size of mutual funds that must also be considered by investors before deciding to invest in these mutual funds.

Several previous studies in various countries also paid attention to mutual funds both in general and in relation to Islamic mutual funds.Mansor and Bhatti ${ }^{5}$ conducted research on 128 Sharia Mutual Funds in the period 1990 to 2009. The Mansor and Bhatti Research aims to determine the performance of

${ }^{5}$ Mansor,Fadillah, Bhatti,M.Ishaq. "The Islamic Mutual Fund Performance: New Evidence on Market Timing and Stock selectivity". International Conference on Economics and Finance Research IPEDR, Vol.4, 2011.
ShariaMutual Funds using the performance measures of Sharpe, Treynor and Jensen. The results showed that in Malaysia, the are positive effect on stock selectivity skills and market timing abilities to the performance of shariamutual funds.

Research Mansor and Bhatti support several other studies such as Ippolito ${ }^{6}$ who got the result that there ispositive effect on stock selectivity skill to the performance in 143 mutual funds in the period 1965 to 1984. Lee and Rahman ${ }^{7}$ in their study of 93 mutual funds in the 1977 to 1984 period also found that market timing and stock selectivity skills had a positive effect on mutual fund performance.

Lehmann and Modest ${ }^{8}$ and Admati et $a l^{9}$ are also in line with the results that market timing and stock selectivity skills have a positive effect on mutual fund performance.

${ }^{6}$ Ippolito, R. A. "Efficiency With Costly Information: A Study of Mutual Fund Performance, 1965-1984". The Quarterly Journal of Economics, vol. 104,1-23, 1989.

${ }^{7}$ Lee C.-F. , Rahman S., "Market Timing, Selectivity, and Mutual Fund Performance: An Empirical Investigation". The Journal of Business, vol. 63,261, 1990.

${ }^{8}$ Lehmann B. N. , Modest D. M., "Mutual Fund Performance Evaluation: A Comparison of Benchmarks and Benchmark Comparisons". The Journal of Finance, vol. 42, 233-265, 1987.

${ }^{9}$ Admati A. R., et al., "On Timing and Selectivity". The Journal of Finance, vol. 41,715-730, 1986. 
Hayat ${ }^{10}$ in his research in Malaysia in the period 2001 to 2006 also found that shariamutual fund investment managers have good market timing abilities. This means that the performance of shariamutual fundsinfluenced positively bymarket timing ability.

Abdel-Kader and Qing ${ }^{11}$ also conducted research examining stock selectivity skills and market timing abilities and their effects on mutual fund performance. Abdel-Kader and Qing use treynor and jensen performance measures. This research was conducted in the period 1995 to 2005 in Hong Kong. Abdel-Kader and Qing's findings in his research are that stock selectivity skills and market timing abilities have no effect on mutual fund performance. This happened because mutual funds underperformed the market.

Cesari and

Panetta ${ }^{12}$ estimated the performance of mutual funds using the jensen method in Italy from 1984 to 1995. Cesari and Panetta focused on market timing abilities using the

\footnotetext{
${ }^{10}$ Hayat, R. “An Empirical Assessment of Islamic Equity Fund Returns" Free University, Amsterdam, 2006.

${ }^{11}$ Abdel-Kader,M., Qing, KY. "Riskadjusted performance, selectivity, timing ability and performance of Hong Kong Mutual Funds". Journal of Asia-Pacific Business. 8(2), .25-58, 2007.

${ }^{12}$ Cesari, R., Panetta F. "The Performance of Italian Mutual Funds". Journal of Banking and Finance, 26: 99-126, 2002.
}

Treynor Mazuy models ${ }^{13}$ and Henriksson Mertonmodels 14. The results showed that the market timing coefficient rarely showed significant positive results. Cesari and Panetta concluded that investment managers were not successful in anticipating movements in the stock market.

See and Jusoh's ${ }^{15}$ research on the effect of risk and size of mutual funds in Malaysia with a sample of 44 conventional mutual funds and 25 sharia mutual funds and using several regression analyzes found that the risk had a positive effect on mutual fund performance. This means that the findings of See and Jusoh support the statement of high risk high return. See and Jusoh in their findings stated that the size of the mutual fund does not affect the performance of the mutual fund. This means that investors will focus on choosing mutual funds based on their level of risk preference.

\footnotetext{
${ }^{13} J$. Treynor., K. Mazuy. 1966. Can Mutua Funds Outguess the Market?. Harvard business review. 1966.

${ }^{14}$ Henriksson, Roy D.Merton, Robert C. On Market Timing and Investment Performance. II. Statistical Procedures for Evaluating Forecasting Skills. The Journal of Busines. 1981.

${ }^{15}$ See,Yong Pui, Jusoh,Ruzita. "Fund Characteristics and Fund Performance: Evidence of Malaysian Mutual Funds". International Journal of Economics and Management Sciences, 1 (9):31-43. 2012.
} 

Ability, Risk, Size, and Comparison of Performance Sharia Mutual Funds

Chang ${ }^{16}$ used beta and size to determine which one will produce a high return. Chang's research results show that mutual funds that have a low beta will provide a high return.Chen $e t$ alli conducted a study of performance based on the size of the fund. The results of his study showed that the size of the mutual fund is very influential on the performance of the study period 1962 to 1999.

Gallagher and Martin ${ }^{18}$ who examined mutual fund performance from 1991 to 2000 in Australia, found that between small and large size mutual fundsthere was no difference in performance. Ferreiraand Matos ${ }^{19}$ in their research in 19 countries produced that performance would be higher if the mutual fund was large. This means that there is a positive relationship between

${ }^{16}$ Chang, K.P. "Evaluating Mutual Fund Performance: An Application of Minimum Convex Input Requirement Set Approach." Computer and Operation Research. Vol 31, 525-533, 2004.

${ }^{17}$ Chen, J., Hong, H., Huang, M. and Kubik, J.D. "Does Fund Size Erode Mutual Fund Performance? The Role of Liquidity and Organization". American Economic Review,Vol 94, 5, 1276-1302,2004.

\footnotetext{
${ }^{18}$ Gallagher, D., Martin, K. "Investment Manager Characteristics, Strategy, Top Management Changes and Fund Performance". Journal of Accounting and Finance. Vol 43, 283-309,2005.

${ }^{19}$ Ferreira, M., Matos, P. “The Colours of Investor Money: The Role of Institutional Investor Around The World". Working Paper. 2006.
}

performance and the size or size of mutual funds in the period 1999 to 2005.

Based on the explanation, the existence of a variety of research results and research gaps, then this study will reexamine the effect of stock selectivity skills, market timing abilities, risk and size on the performance of shariamutual fund. The focus of this research is on sharia equity funds because of interest in the rapid development of sharia products, especially sharia financial products in Indonesia.

\section{Literature review}

\section{Mutual Funds}

Mutual funds can be interpreted as a container to be used to collect funds from investors, then these funds will be invested in the form of investment portfolios by investment managers ${ }^{20}$. Investment managers will manage the funds collected in the form of portfolios, such as stocks, bonds, or in the form of other securities. Mutual funds are a form of investment for people who have little time and capital and limited expertise, but have the desire to invest.

\footnotetext{
${ }^{20}$ Undang-Undang Republik Indonesia Nomor 8 Tahun 1995 pasal 1 ayat 27 tentang Pasar Modal. https://www.ojk.go.id/id/kanal/pasarmodal/regulasi/undangundang/Documents/Pages/undangundang-nomor-8-tahun-1995-tentang-pasarmodal/UU\%20Nomor\%208\%20Tahun\%201 995\%20(official).pdf)
} 
Investors will get many benefits if investing in mutual funds. Mutual funds as a forum for small investors to participate in development and invest in companies. Considerable funds will be collected if investing in mutual funds. The greater the mutual fund, the greater the ability to diversify investments, so the smaller the risk will be faced ${ }^{21}$. Some investors have limited knowledge and expertise in determining which financial instruments should be purchased or not, the solution is to invest in mutual funds, because this mutual fund is managed by an investment manager that is a professional who is certainly an expert in such matters, so investors in mutual funds do not have to always see or monitor how the investment performance. Time efficiency is also another benefit of mutual funds.

An important quantity in mutual funds is NAVperunit (net asset value of the participant's unit). NAV is used to determine the price calculated every day. The NAV calculation is based on the previous day's closing price announced to the public. "NAVperunit is the buying price or selling price per unit of investment that investors must pay. Changes in NAV perunit provide

\footnotetext{
${ }^{21}$ Hadi, N. Pasar Modal Acuan Teoretis dan Praktis Investasi di Instrumen Keuangan Pasar Modal. Yogyakarta: Graha Ilmu. 2013 :132.
}

indicators of investment performance of a mutual fund "22

\section{ShariaMutual Funds in Indonesia} In Indonesia, Officially launchedthe Islamic capital market on March 14, 2003. This was marked by the signing of a MOU between the Capital Market and Financial Institution Supervisory Agency (BAPEPAM-LK) and the National Sharia Council of the Indonesian Ulema Council (DSN-MUI). In fact, in Indonesia, Islamic capital market instruments have existed since 1997. This is because PT Danareksa Investment Management on July 3, 1997 issued Danareksa ShariaProducts. Further development, the Indonesia Stock Exchange took PT Danareksa Investment Management on July 3, 2000, to issue the Jakarta Islamic Index (JII) with the aim of providing information on performance benchmarks. This is can be used as a basis of sharia principles for investors.

MUI Fatwa No.20 / DSN-MUI / IV / $2001{ }^{23}$ explains sharia mutual funds are "mutual funds operating according to Islamic sharia principles and principles, both in the form of a contract between the investor as the owner of the asset (Sahib al-mal or

\footnotetext{
${ }^{22}$ Pratomo, E. P., Nugraha, U. Reksa Dana Solusi Perencanaan Investasi di Era Modern. Jakarta: PT.Elex Media Komputindo. 2009 :52-53.

${ }^{23}$ Fatwah Dewan Syariah Nasional https://dsnmui.or.id/kategori/fatwa/page /11/
} 

Ability, Risk, Size, and Comparison of Performance Sharia Mutual Funds

Rabb al Mal) with investment manager as representative of shahib al-mal, and between investment manager as representative of shahib al-mal with investment users ". There are differences between conventional and sharia mutual funds. The difference is that there is a screening and cleansing process in the entire portfolio management process in Islamic mutual funds. The screening process is the process of screening securities in accordance with Islamic law, while the cleansing process is a process of elimination. If in the management of Islamic mutual fund portfolios are not in accordance with with Islamic rules, those benefits must be issued and practiced ${ }^{24}$. Investment portfolios that are in accordance with Islamic law will be formed through a screening and cleansing process.

MUI Fatwa No.20/DSNMUI/IV/2001 article 2 describes the operational mechanism of sharia mutual funds. Consists of two things, namely the first time, namely between investment managers and financiers. Investment managers are given a mandate by investors to make investments according to the provisions in the prospectus for the interests of investors. Second, the mudharabah system, between investment users and investment managers. The mudharabah concept is profit sharing between users and

\footnotetext{
${ }^{24}$ Otoritas Jasa Keuangan. POJK

Nomor 19/POJK.04/2015.

https://www.ojk.go.id/id/kanal/syariah/r egulasi/peraturan-ojk-terkait-

syariah/Pages/POJK-19POJK042015.aspx
}

shahib al-mal or financiers represented by investment managers. This is based on the proportions agreed by both parties. Furthermore, the risk is borne by the investor in the amount of the funds that have been deposited. The risk of loss on investment is not borne by the investment manager unless the error is due to negligence of the investment manager (tafrith or gross negligence).

\section{Mutual Funds Performance-Sharpe, Treynor and Jensen methods}

The method used to assess the performance of investment portfolios usually uses sharpe, treynor and jensen indexes or methods"25. The sharpe method is measured and determined by comparing the portfolio risk premium with the risk that is the standard deviation or total risk. Risk premium is the result of the difference or the difference between the average profit of the portfolio and the average risk-free interest rate). Portfolio performance will be better if the ratio between risk premium and standard deviation is greater.

The measurement using the treynor method is determined comparing the portfolio risk premium and the risk that is beta. Beta is a market risk or systematic risk. The greater the ratio of risk premium to beta which shows a better portfolio performance.

${ }^{25}$ Halim, A. Analisis Investasi. Jakarta: Salemba Empat. 2005: 51. 
The Security Market LineSML concept that underlies the use of the Jensen method is a conneting stripe between risk-free investment opportunities and market portfolios. Beta risk is used by Jensen in determining portfolio investment performance. The Jensen index will be positive, if the profit equal to the SML equation is smaller than the actual return of the portfolio. Conversely, the Jensen index will be negative if the return that matches or equals the SML equation is greater than the actual profit of the portfolio. Jensen's index, the better the performance the higher the alpha (a) value.

When using the Jensen
method measurement, shariamutual funds have better performance than conventional ${ }^{26}$. This is because the performance based on the Jensen method is judged by the ability of investment managers to make market performance lower than mutual fund performance. This is certainly adjusted to the risks that exist in mutual funds. Regarding risk, shariaassets have lower risks, so they have a higher level of security.

\section{Stock selectivity skill}

Stock selectivity skill is the competence to select the appropriate assets to create a portfolio owned by an investment manager. This ability

26Lailiyah, EH., Suhadak., Sulasmiyati, S. 2016. Analisis Perbandingan Kinerja Reksadana Syariah dan Reksadana Konvensional. Jurnal Administrasi Bisnis, 5 (2) : 114-121. is the ability to predict assets that can produce abnormal returns or superior returns than expected in the future.

\section{Market timing ability}

Market timing ability is the skill of an investment manager in determining the accuracy of a policy to buy or sell certain assets and securities. This means that this ability aims to create an asset portfolio at the right time. Calculation of stock selectivity skills and market timming abilities are used to calculate the Treynor Mazuy Model (1966). This model can be seen from the notation $a$. The a value can indicate the ability of an investment manager's stock selection skills. If the value of $a$ is greater than 0 or is positive, then the ability of investment managers is getting better. The Treynor-Mazuy Model also contains a notation which illustrates the ability of investment managers in market timing. If $\gamma$ is positive or greater than 0 , then it is concluded that investment managers have good market timing capabilities

\section{Risk}

Risk is important,in investing investors need to pay attention not only in return, but also in risks. In general, we calculate standard deviation or beta to measuring the risk. Systematic risk for a company or portfolioare a Beta.Robert Ang in Hadi $^{27}$ explained that beta is used in

\footnotetext{
${ }^{27}$ Hadi, N. Pasar Modal Acuan Teoretis dan Praktis Investasi di Instrumen Keuangan
}

144| Copyright (C) 2020, IQTISHODUNA: Jurnal Ekonomi Islam

http://ejournal.iaisyarifuddin.ac.id/index.php/iqtishoduna 
measuring market risk or nondiversifiable risk. Market risk can be interpreted as a risk caused by market factors such as political or economic factors, a high Beta implies a high level of risk as well.

Samsul28also explained that beta can show the size, that is, the size or the change of a mutual fund's profit from market returns. Beta measurement or systematic risk uses a model that has been developed by William Sharpe, the Single Index Method.

\section{Size of mutual funds}

The size of a mutual fund is the managed fund, that isinvestment managermanaged the amount of the fund. The size of the managed fund can provide its own advantages when compared to the small size of the managed fund. The amount of funds managed by an investment manager will have an impact on the ability of investment managers to diversify their funds. This means that investment managers will get more investment opportunities than investment managers with smaller managed funds. The more diversification, the greater the benefits obtained with smaller risks. The total managed fund of each investment company is used as a

Pasar Modal. Yogyakarta: Graha Ilmu. 2013:203.

\footnotetext{
${ }^{28}$ Samsul, Mohamad. Pasar Modal E Manajemen Portofolio. Surabaya: Erlangga. $2006: 363$.
}

measure of mutual funds in this study.

Based on the background, objectives, literature review and previous research findings, hypotheses in this study can be formulated, namely stock selectivity skills, market timing abilities, risks, and sizes partially influence the performance of shariamutual funds.

\section{Research Methods}

\section{Research Types and Samples}

This study uses a quantitative approach and was conducted in the period of 2012 to 2017. The sample was determined by purposive sampling technique with certain criteria, namely mutual funds are types of sharia shares registered at the Financial Services Authority(OJK) and have an effective date before the research period, namely before 2012, so a sample of seven Islamic mutual fund shares was obtained.

\section{Data collection}

The data in this study are secondary data collected from the website of the Financial Services Authority (OJK), Bank Indonesia, Indonesia Stock Exchange and Bareksa. The data used is asset under management and unit investment.Data of each mutual fund, SBIS, closing price of the Jakarta Islamic Index (JII).

\section{Measurement variables and Analysis Methods}


Table 1 is a measurement of the dependent and independent variables in this study, presented as follows:

Table 1. Measurement of Dependent and Independent Variables

\begin{tabular}{|c|c|c|c|}
\hline No & Variable & Measurement & Explanation \\
\hline 1 & $\begin{array}{l}\text { Sharpe } \\
\text { Ratio }\end{array}$ & $5_{p i}=\frac{\text { Fpi-Rf }}{5 D_{p i}}$ & $\begin{array}{l}\text { Rpi }=\text { portfolio return } \\
\mathrm{Rf}=\text { risk free rate } \\
\text { SDpi=standard } \\
\text { deviation }\end{array}$ \\
\hline 2 & $\begin{array}{l}\text { Treynor } \\
\text { Ratio }\end{array}$ & $T_{p i}=\frac{\text { Fpi-Ri }}{\beta p i}$ & $\begin{array}{l}\text { Rpi = portfolio return } \\
\mathrm{Rf}=\text { risk free rate } \\
\beta p i=\text { beta portfolio }\end{array}$ \\
\hline 3 & $\begin{array}{l}\text { Jensen } \\
\text { Ratio }\end{array}$ & $\begin{array}{l}\text { Jpi=(Rpi-Rf) - } \\
\text { (Rm-Rf) } \beta p i\end{array}$ & $\begin{array}{l}\mathrm{Rpi}=\text { portfolio return } \\
\mathrm{Rf}=\text { risk free rate } \\
\mathrm{Rm}=\text { market return } \\
\beta_{p i}=\text { beta portfolio }\end{array}$ \\
\hline 4 & $\begin{array}{l}\text { Stock } \\
\text { Selectivity } \\
\text { Skill }\end{array}$ & & \multirow{2}{*}{$\begin{array}{l}\text { Using the Treynor } \\
\text { Mazuy Model (1966). } \\
\text { Stock selection skills } \\
\text { are indicated by a. if } a> \\
0 \text {, then the investment } \\
\text { manager has stock } \\
\text { selectivity skills. } \\
\text { Market timing abilities } \\
\text { are indicated by } \gamma \text {. if } \gamma> \\
\text { 0, then the investment } \\
\text { manager has a market } \\
\text { timing ability. }\end{array}$} \\
\hline 5 & $\begin{array}{l}\text { Market } \\
\text { Timing } \\
\text { Ability }\end{array}$ & $\begin{array}{l}R_{i}-R_{f}=\alpha+\beta \\
\left(R_{m}-R_{f}\right)+\gamma \\
\left(R_{m}-R_{f}\right)^{2}+\varepsilon\end{array}$ & \\
\hline 6 & Risk & $\begin{array}{l}R_{i}=\alpha+\beta \cdot R_{m} \\
+\varepsilon\end{array}$ & $\begin{array}{l}\text { Use the single index } \\
\text { model to determine } \\
\text { beta }\end{array}$ \\
\hline 7 & Size & SIZE $=\operatorname{Ln}(\mathrm{NAV})$ & $\begin{array}{l}\text { Use natural logarithms } \\
\text { to simplify values. }\end{array}$ \\
\hline
\end{tabular}

Data analysis uses multiple linear regression. Data processing using SPSS 21 and Microsoft Excel. The following is a regression model in this study:

Sharpe $_{i t}=\beta_{0 i t}+\beta_{1}$ SELECT $_{i t}+$ $\beta_{2}$ MARTIM $_{i t}+\beta_{3}$ RISK $_{\text {it }}+\beta_{4}$ SIZE $_{\text {it }}$

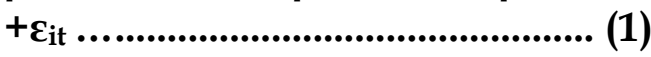

Treynor $_{i t}=a_{0 i t}+\alpha_{1}$ SELECT $_{i t}+$ $\alpha_{2}$ MARTIM $_{i t}+\alpha_{3}$ RISK $_{\text {it }}+\alpha_{4}$ SIZE $_{\text {it }}$ $+\boldsymbol{\epsilon}_{\text {it }}$

Jensen $_{\text {it }}=\gamma_{0 i t}+\beta_{1}$ SELECT $_{\text {it }}+\gamma$ ${ }_{2}$ MARTIM $_{i t}+\gamma_{3}$ RISK $_{i t}+\gamma_{4}$ SIZE $_{i t}$ $+\mathrm{e}_{\mathrm{it}}$

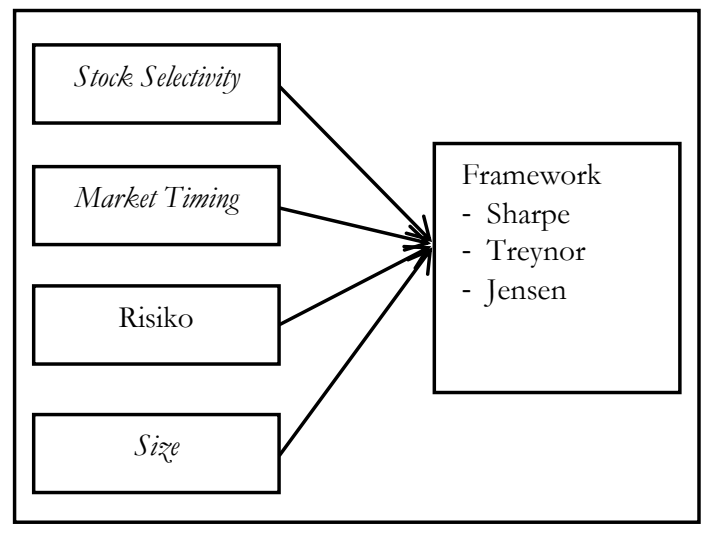

Figure 2. Conceptual framework

\section{Results and Discussion}

In the analysis model that has been formed has been tested classic assumptions. The classical assumption test results in all three models have fulfilled so that the data has been normally distributed, there is no heterocedasticity, there is no autocorrelation and there is no multicollinearity. The following are the results of the regression equation in this study:

\section{Sharpe $\quad=\quad-1,455 \quad+$ 15,158SELECT $+\quad$ 0,020MARTIM+ 0,298RISK+ 0,054SIZE}

Treynor $=-0,036+$ 0,438SELECT $+\quad$ 0,000MARTIM+ 0,006RISK+ 0,001SIZE

$\begin{array}{lcr}\text { Jensen } \quad= & -0,017 \\ \text { 0,240SELECT }+ & 0,000 \text { MARTIM+ } \\ \text { 0,004RISK }+ \text { 0,001SIZE }\end{array}$


Elliv Hidayatul Lailiyah, Rahmat Setiawan: Stock Selectivity Skill, Market Timing Ability, Risk, Size, and Comparison of Performance Sharia Mutual Funds

Table 2. Regression results from the effect of stock selectivity skills, market timing ability, risk and size on the performance of Islamic mutual fund (sharpe, treynor, and jensen)

\begin{tabular}{|c|c|c|c|}
\hline \multirow{2}{*}{$\begin{array}{c}\text { Independen } \\
\text { Variable }\end{array}$} & \multicolumn{3}{|c|}{ Dependen Variable } \\
\hline & Sharpe & Treynor & Jensen \\
\hline $\begin{array}{ll}\text { 1. } & \text { Stock } \\
\text { Selectivity } \\
\text { Skill }\end{array}$ & $\begin{array}{c}15,158 \\
(0,026)^{* *}\end{array}$ & $\begin{array}{c}0,438 \\
(0,000)^{*}\end{array}$ & $\begin{array}{c}0,240 \\
(0,002)^{*}\end{array}$ \\
\hline $\begin{array}{l}\text { 2. Market } \\
\text { Timing }\end{array}$ & $\begin{array}{c}0,020 \\
(0,006)^{*}\end{array}$ & $\begin{array}{c}0,000 \\
(0,004)^{*}\end{array}$ & $\begin{array}{c}0,000 \\
(0,027)^{* *}\end{array}$ \\
\hline 3. Risk & $\begin{array}{c}0,298 \\
(0,047)^{* *}\end{array}$ & $\begin{array}{c}0,006 \\
(0,001)^{*}\end{array}$ & $\begin{array}{c}0,004 \\
(0,002)^{*}\end{array}$ \\
\hline 4. Size & $\begin{array}{c}0,054 \\
(0,039)^{\star *}\end{array}$ & $\begin{array}{c}0,001 \\
(0,003)^{*}\end{array}$ & $\begin{array}{c}0,001 \\
(0,025)^{* *}\end{array}$ \\
\hline $\begin{array}{l}\mathrm{R}^{2} \\
\text { Adj. } \mathrm{R}^{2}\end{array}$ & $\begin{array}{l}0,775 \\
0,722\end{array}$ & $\begin{array}{l}0,928 \\
0,911\end{array}$ & $\begin{array}{l}0,869 \\
0,831\end{array}$ \\
\hline
\end{tabular}

*Significant at $1 \%$

** Significant at $5 \%$

Source: Processed research data

The effect of stock selectivity skills on the performance of sharia mutual fund

The skills of investment managers to choose stocks or stock selectivity skills will affect the performance of shariamutual fund, as indicated by the SELECT variable that produces positive coefficients (Sharpe 15.158; Treynor 0.438; Jensen 0.240 ) and significant (Sharpe 0.026 $<0.05$; Treynor $0.000<0.01$; Jensen $0.002<0.01)$. This result is reasonable and not surprising because of the large returns for mutual fund investors because investment managers have chosen the right stock in forming a portfolio.

Based on the regression results using each model, the three models have no difference and have the same results. This means that the first hypothesis in this study was accepted. The results of this study support the research of Mansor and Bhatti (2011), Ippolito (1989), Lehmann and Modest (1987), Lee and Rahman (1990) and Admati et al (1986).

\section{The effect of market timing ability on the performance of sharia mutual fund \\ MARTIM variable which} shows the skills of investment managers in market timing when investing funds from mutual funds. There is positive effecton market timing ability to the performance of shariamutual fund. The measurements of the sharpe, treynor and jensen methods show the same results. That is, the second hypothesis in this study was accepted. This is evidenced by the positive and significant regression coefficient (Sharpe $0.006<0.01$; Treynor $0.004<0.01$; Jensen 0.027 $<0.05)$. This supports several previous studies such as Mansor and Bhatti (2011), Lehmann and Modest (1987), Lee and Rahman (1990), Admati et al (1986), and Hayat (2006).

\section{Effect of risk on the performance of shariamutual fund}

RISK variables show positive coefficients (Sharpe 0,298; Treynor 0,006 ; Jensen 0,004) and significant (Sharpe 0,047<0,05; Treynor 0,006 $<0.01$; Jensen $0,004<0.01$ ) which indicate that high risk will give high performance. This means that the third hypothesis in this study was accepted. These results support the concept of high risk high return. This 
means that the higher the profit to be obtained, the higher the risk of an investment. Mutual funds are an alternative investment with low risk because there is a high diversification, where diversification will reduce the level of risk but will get a high return. Investors will focus on choosing mutual funds based on their level of risk preference. These results support the research of See and Jusoh (2012) in Malaysia.

The effect of size on the performance of shariastock mutual funds

Consistent results on the three mutual fund performance measurement models were also found on the SIZE variable, namely the size or size of the managed fund of mutual funds had a positive effect on the performance of shariamutual fund funds. This is evidenced by the positive coefficient SIZE (Sharpe 0.054; Treynor 0.001; Jensen 0.001) and significant (Sharpe $0.039<0.05$; Treynor $0.003<0.01$; Jensen 0.025 $<0.005)$. This means that the fourth hypothesis in this study was accepted. These results support the research of Chen et al (2004) and Ferreira and Matos (2006) which states that the size of a mutual fund has a positive effect on mutual fund performance.

The effect of stock selectivity skills, market timing ability, risk and size on the performance of shariamutual fund funds

Based on table 2, adjusted $\mathrm{R}^{2}$ in model 1 is 0.722 , which means mutual fund performance when measured by the sharpe method is influenced by stock selectivity skills, market timing abilities, risk and size by $72.2 \%$ while $27.8 \%$ is influenced by other variables. Adjusted $\mathrm{R}^{2}$ in model 2 is 0.911, which means mutual fund performance when measured by the Treynor method is influenced by stock selectivity skills, market timing ability, risk and size by $91.1 \%$ while $8.9 \%$ is influenced by other variables. The adjusted $\mathrm{R}^{2}$ model 3 is 0.831 , meaning that the mutual fund performance when measured by the Jensen method is influenced by stock selectivity skills, market timing ability, risk and size by $83.1 \%$ while $16.9 \%$ is influenced by other variables. The difference in the level of $R^{2}$ between the three methods used does not seem far. The effect of stock selectivity skills, market timing ability, risk and size on mutual fund performance will be very strong when measured by the Treynor method compared to Sharpe and Jensen methods.

\section{Conclusion}

Based on the three methods, the same results are obtained namely stock selectivity skills, market timing abilities, risks and size have a positive effect on the performance of shariamutual fund. This means that the performance of shariastock mutual funds during the period 2012 to 2017 is influenced by stock selectivity skills, market timing abilities, risk and size. The effect of the independent variable will very strong when measured using the

148| Copyright (C) 2020, IQTISHODUNA: Jurnal Ekonomi Islam

http:/ / ejournal.iaisyarifuddin.ac.id/index.php/iqtishoduna 
Elliv Hidayatul Lailiyah, Rahmat Setiawan: Stock Selectivity Skill, Market Timing Ability, Risk, Size, and Comparison of Performance Sharia Mutual Funds

Treynor method performance measurement.

\section{REFERENCES}

Abdel-Kader,M., Qing, KY. "Riskadjusted performance, selectivity, timing ability and performance of Hong Kong Mutual Funds". Journal of AsiaPacific Business. 8(2), .25-58, 2007.

Admati A. R., et al., "On Timing and Selectivity". The Journal of Finance, vol. 41,715-730, 1986.

Badan Pusat Statistik. Penduduk Menurut Wilayah dan Agama yang Dianut. (Online), (http://sp2010.bps.go.id/index .php/site/tabel?tid=321) accessed on 17 November 2018.

Bursa Efek Indonesia. Pengantar Pasar Modal. (Online),(http://www.idx.co.id /investor/pengantar-pasarmodal/), accessed on 17 November 2018.

Cesari, R., Panetta F. "The Performance of Italian Mutual Funds". Journal of Banking and Finance, 26: 99-126, 2002.

Chang, K.P. "Evaluating Mutual Fund Performance: An Application of Minimum Convex Input Requirement Set Approach." Computer and Operation Research. Vol 31, 525533, 2004.

Chen, J., Hong, H., Huang, M. and Kubik, J.D. “Does Fund Size Erode Mutual Fund Performance? The Role of Liquidity and Organization".
American Economic Review, $\mathrm{Vol}$ 94, 5, 1276-1302, 2004.

Gallagher, D., Martin, K. "Investment Manager Characteristics, Strategy, Top Management Changes and Fund Performance". Journal of Accounting and Finance. Vol 43, 283-309, 2005.

Fatwa Dewan Syariah Nasional Majelis Ulama Indonesia Nomor 20/DSN-MUI/IV/2001 tentang Pedoman Pelaksanaan Investasi untuk Reksadana Syariah.(Online),(www.dsnmui .or.id).accessed on 06 Januari 2019.

Ferreira, M., Matos, P. “The Colours of Investor Money: The Role of Institutional Investor Around The World". Working Paper. 2006.

Hadi, N. Pasar Modal Acuan Teoretis dan Praktis Investasi di Instrumen Keuangan Pasar Modal. Yogyakarta: Graha Ilmu. 2013.

Halim, A. 2005. Analisis Investasi. Jakarta: Salemba Empat.

Hayat, R. 2006. An Empirical Assessment of Islamic Equity Fund Returns. Free University, Amsterdam.

Henriksson, Roy D. Merton, Robert C. 1981. On Market Timing and Investment Performance. II. Statistical Procedures for Evaluating Forecasting Skills. The Journal of Busines.

Ippolito, R. A. "Efficiency With Costly Information: A Study of Mutual Fund Performance, 1965-1984". The Quarterly 
Journal of Economics, vol. 104,123, 1989.

J. Treynor., K. Mazuy. 1966. Can Mutua Funds Outguess the Market?. Harvard business review.

Lailiyah, EH., Suhadak., Sulasmiyati, S. 2016. Analisis Perbandingan Kinerja Reksadana Syariah dan Reksadana Konvensional. Jurnal Administrasi Bisnis , 5 (2) : 114-121.

Lehmann B. N. , Modest D. M., "Mutual Fund Performance Evaluation: A Comparison of Benchmarks and Benchmark Comparisons". The Journal of Finance, vol. 42, 233-265, 1987.

Lee C.-F. , Rahman S., "Market Timing, Selectivity, and Mutual Fund Performance: An Empirical Investigation". The Journal of Business, vol. 63,261, 1990.

Mansor, Fadillah, Bhatti,M.Ishaq. "The Islamic Mutual Fund Performance: New Evidence on Market Timing and Stock selectivity". International Conference on Economics and Finance Research IPEDR, Vol.4, 2011.

Otoritas Jasa Keuangan. Statistik Reksadana Syariah. (Online), (https://www.ojk.go.id/id/kan al/syariah/ data-danstatistik/reksa-danasyariah/default.aspx), accessed on 17 November 2018.
Otoritas Jasa Keuangan. POJK Nomor 19/POJK.04/2015. (Online), (https://www.ojk.go.id/id/kan al/syariah/regulasi/peraturanojk-terkait-syariah/Pages/POJK19POJK042015.aspx). accessed on 06 Januari 2019.

Pratomo, E. P., Nugraha, U. 2009. Reksa Dana Solusi Perencanaan Investasi di Era Modern. Jakarta: PT.Elex Media Komputindo.

Samsul, Mohamad. 2006. Pasar Modal $\mathcal{E}$ Manajemen Portofolio. Surabaya: Erlangga.

See,Yong Pui, Jusoh,Ruzita. "Fund Characteristics and Fund Performance: Evidence of Malaysian Mutual Funds". International Journal of Economics and Management Sciences,1 (9):3143. 2012.

Undang-Undang Republik Indonesia Nomor 8 Tahun 1995 tentang Pasar

Modal.(Onlinehttps://www.ojk. go.id/id/kanal/pasarmodal/regulasi/undangundang/Documents/Pages/und ang-undang-nomor-8-tahun1995-tentang-pasarmodal/UU\%20Nomor \% 208\%20 Tahun\%201995\%20(official).pdf), accessed on 17 November 2018. 